\title{
SAUSŲ AKIŲ SINDROMO IŠRAIŠKA SERGANT GREIVSO OFTALMOPATIJA
}

\author{
Laura Kapitanovaitė ${ }^{1}$, Simas Giedrys ${ }^{1}$, Jūratė Jankauskiené², \\ ${ }^{1}$ Lietuvos sveikatos mokslu universiteto Medicinos akademijos Medicinos fakultetas, \\ ${ }^{2}$ Lietuvos sveikatos moksly universiteto Kauno kliniku Akiu ligu klinika
}

Raktažodžiai: sausų akių sindromas, Greivso oftalmopatija, sausų akių liga, Greivso liga, egzoftalmetrija, akių paviršiaus ligų klausimynas.

\begin{abstract}
Santrauka
Literatūros duomenimis, Greivso oftalmopatija (GO) sergantiems pacientams sausų akių sindromas (SAS) yra diagnozuojamas $65 \%-85 \%$ atvejų. SAS apibūdinama kaip ịvairių veiksnių sukeliama akies paviršiaus liga, kuri pasireiškia akių diskomforto simptomais. Sergant Greivso liga, sausų akių sindromas atsiranda dẻl padidejjusio akies išverstakumo, voko retrakcijos ir sumažèjusios ašarų gamybos. Tyrimo tikslas - nustatyti sausų akių sindromo pasireiškimą tarp pacientų, sergančių Greivso oftalmopatija, ir ivvertinti simptomų stiprumo ryši su išverstakumo dydžiu. Tyrimo metodas - vienmomentinè anoniminè anketinè apklausa ir Hertelio egzoftalmetrinis tyrimas. Sudaryta originali anketa apie dažniausius sausų akių simptomus ir jų ịtaką kasdienei veiklai. Įvertinus rezultatus prieita prie išvadų, jog GO sergantiems pacientams didžiausią ịtaką gyvenimo kokybei turi ir labiausiai vargina akių jautrumas šviesai ir akių niežulys, Hertelio egzoftalmetru nustatytas vidutinis dešinès ir kairès akies išverstakumas viršijo normos ribas. Nustatyta statistiškai reikšminga tiesioginė koreliacija tarp išverstakumo dydžio ir akių jautrumo šviesai, niežulio ir skausmo stiprumo.
\end{abstract}

\section{Ivadas}

Sausų akių sindromas (SAS) yra viena dažniausių oftalmologinių problemų pasaulyje, kuri paveikia nuo 7,4 \% iki 33,7 \% visos populiacijos [1]. SAS apibūdinama kaip ìvairių veiksnių sukeliama ašarų plèvelès ir akies paviršiaus liga, kuri pasireiškia akių diskomfortu, regos sutrikimais [2]. Sausų akių sindromas gali pasireikšti ịvairiais simptomais - akių perštejjimu, niežuliu, svetimkūnio pojūčiu akyse, re- gèjimo pablogèjimu, akių sausumu.

Dažniausia liga, kuria sergant diagnozuojamas sausų akių sindromas, yra Greivso liga. Ši liga yra autoimuninès kilmès, pažeidžia skydliaukę, akis ir retais atvejais odą. $2017 \mathrm{~m}$. Lietuvos higienos instituto Sveikatos informacijos centro duomenimis, hipertirozė buvo nustatyta $3,77 / 1000$ suaugusiujų [3]. Dažniausia šios ligos išraiška yra Greivso oftalmopatija (GO, endokrininè oftalmopatija, Greivso akių liga) [4], kuri būna $25-50 \%$ sergančiųjų kartu su hipertiroidizmu arba per 18 mènesių nuo ligos pradžios [5].

Greivso oftalmopatijos klinikiniai požymiai ir simptomai išsivysto dèl akių tiesiụjų raumenų ir aplinkinių audinių limfocitinès infiltracijos, edemos aktyvioje GO fazèje ir fibrozès neaktyvioje fazeje [1]. Vienas pagrindinių GO klinikinių požymių yra išverstakumas, kurị sukelia padidejęs akiduobès tūris dèl audinių uždegimo. Išverstakumas matuojamas egzoftalmetru. Nustatyta, kad Europos baltaodžių egzoftalmetrijos rodikliai, kurie yra mažesni nei $20 \mathrm{~mm}$, vertinama kaip norma, 21-23 mm- minimalus išverstakumas, 24-27 mm - vidutinis ir daugiau nei $28 \mathrm{~mm}$ - ryškus išverstakumas [6]. Lietuvos tyrimų duomenimis, sveikiems jauniems žmonėms išverstakumo rodikliai, matuojant Hertelio egzoftalmometru yra 16,02 $\pm 1,9 \mathrm{~mm}$ [6]. Esant Greivso oftalmopatijai SAS išsivysto dèl padidejjusio akies atidengimo, sukeliamo išverstakumo ir voko retrakcijos. Taip pat šiam sindromui išsivystyti įtakos turi sumažejusi ašarų gamyba ir padidejjęs jų išgaravimas. Literatūros duomenimis, pasaulyje GO sergantiems pacientams SAS yra diagnozuojamas $65 \%-85 \%$ atvejų [1]. Sausų akių sindromas pacientams yra diagnozuojamas remiantis ịvairiais standartizuotais klausimynais, pvz., akių paviršiaus ligų klausimynu (angl. OSDI), standartiniu pacientų akių sausumo vertinimo klausimynu (ang. SPEED) ir remiantis Širmerio ašarų testu.

Darbo tikslas: nustatyti sausų akių sindromo (SAS) pasireiškimą tarp pacientų, sergančių Greivso oftalmopatija (GO), ir įvertinti simptomų stiprumo ryši su išverstakumo dydžiu. 


\section{Tyrimo medžiaga ir metodika}

Tyrimas buvo perspektyviai vykdomas Kauno klinikų Akių ligų konsultacinèje poliklinikoje 2018-2019 metais. Tyrime dalyvavo 77 Greivso oftalmopatija sergantys pacientai. Tyrimo metodas - vienmomentinè anoniminè anketinè apklausa ir Hertelio egzoftalmetrinis tyrimas. Tyrimui buvo sudaryta originali anketa apie dažniausius sausų akių simptomus ir jų įtaką kasdienei veiklai. SAS simptomai (jautrumas šviesai, niežulys, skausmas, smėlio pojūtis, sausumas, susiliejęs matymas, deginimo pojūtis) buvo atrinkti remiantis literatūros šaltiniais ir akių paviršiaus ligų klausimynu (ang. OSDI). Kadangi simptomo pojūtis yra subjektyvus, pacientai turèjo įvertinti kiekvieno simptomo stiprumą 4 balų skaleje, remdamiesi jo daroma įtaka kasdienei veiklai (pvz., simptomo nejaučia (0), simptomą jaučia retai ar beveik nejaučia (1), jaučia, bet netrukdo kasdienei veiklai (2), trukdo kasdienei veiklai (3), trukdo ir neleidžia atlikti ịprastų veiksmų (4). Vizito metu pacientams taip pat buvo matuojamas akių išverstakumas naudojant Hertelio egzoftalmetrą. Vertinant koreliacijas buvo naudojami dešiniosios akies egzoftalmetrijos duomenys. Statistiné duomenų analizè ir skaičiavimai atlikti naudojant „SPSS for Windows 25.0" programą. Aprašomosios statistikos duomenys pateikti vidurkio reikšme ir standartiniu nuokrypiu $(\mathrm{M} \pm \mathrm{SD})$ arba procentais. Kiekybinių požymių pasiskirstymas pagal Gauso skirstinį tikrintas naudojant Šapiro Vilko (Shapiro-Wilk) kriterijų. Ryšio stiprumas tarp skirtingų požymių vertintas Spirmeno (Spearman) koreliacijos koeficientu. Rezultatai laikyti statistiškai reikšmingi, jei $\mathrm{p}<0,05$.

\section{Rezultatai ir jų aptarimas}

Tyrime dalyvavo 5 ( 7 proc.) vyrai ir 72 (93 proc.) moterys. Respondentų amžius vyravo nuo 20 iki 80 metų, vidutinis $-56,9 \pm 12,7$. Klausdami pacientų apie dažniausius jų jaučiamus akių simptomus gavome atsakymus, kad 77,92 proc. $(\mathrm{n}=60)$ tiriamujų skundèsi akių jautrumu šviesai, 70,13 proc. $(\mathrm{n}=54)$ - smèlio pojūčiu akyse, 77,92 proc. $(\mathrm{n}=60)$ - niežuliu, 76,62 proc. $(\mathrm{n}=59)$ - akių sausumu, 50,65 proc. $(\mathrm{n}=39)$ - deginimo pojüčiu, 79,22 proc.(n=61) - akių skausmu, 68,83 proc. $(\mathrm{n}=53)$ - susiliejusiu matymu.

Subjektyviai vertindami pacientų požiūrị ị išvardintų simptomų itaką kasdienei veiklai nustateme, kad didžiausią ịtaką gyvenimo kokybei turejo jautrumas šviesai, kuris 41,56 proc. $(\mathrm{n}=32)$ respondentų trukdè kasdienèje veikloje, ir akių niežulys trukdè 38,6 proc. $(\mathrm{n}=30)$ respondentų. 41,56 proc. $(n=32)$ pacientų jautė akių sausumą ir 42,86 proc. $(n=33)$ akių skausmą, bet šie simptomai kasdienei veiklai netrukdè.

Atlikus matavimus Hertelio egzoftalmetru, vidutinis dešinès akies išverstakumas buvo 17,05 $\pm 1,72 \mathrm{~mm}$, kairiosios $17,64 \pm 1,58 \mathrm{~mm}$. Bazès vidurkis - 99,61 $\pm 2,656 \mathrm{~mm}$.

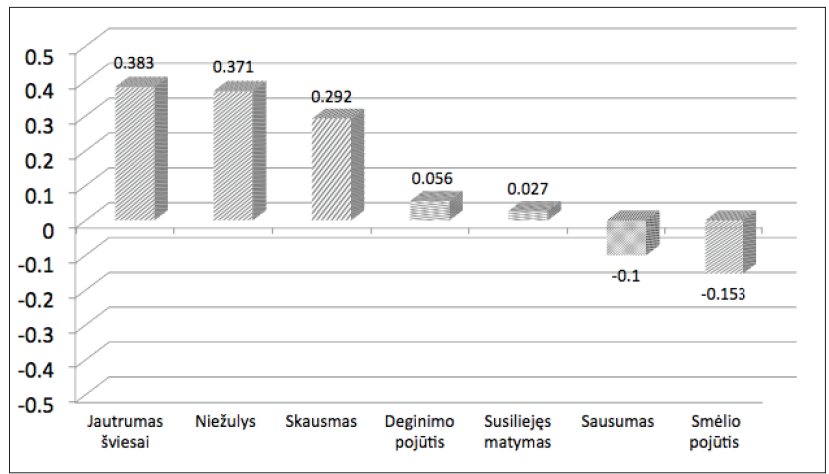

1 pav. Pirsono (Pearson) koreliacijos koeficientas.

Nustatyta statistiškai reikšminga teigiama vidutinio stiprumo priklausomybė tarp išverstakumo dydžio ir akių jautrumo šviesai stiprumo $(r=0,383, p=0,001)$, tarp išverstakumo dydžio ir niežulio stiprumo nustatyta teigiama vidutinio stiprumo priklausomybè $(r=0,371, p=0,001)$, tarp išverstakumo dydžio ir skausmo stiprumo nustatyta silpna tiesioginè priklausomybè $(r=0,292, p=0,01)$. Statistiškai reikšmingos priklausomybès tarp smèlio pojūčio ir išverstakumo dydžio nebuvo nustatyta $(\mathrm{r}=-0,153 \mathrm{p}=0,183)$, akių sausumas taip pat nekoreliavo su išverstakumo dydžiu ( $\mathrm{r}=$ $-0,1, p=0,386)$. Deginimo pojūtis akyse statistiškai reikšmingai nekoreliavo su išverstakumo dydžiu $(r=0,056, p=0,626)$, taip pat ir susiliejęs matymas ( $\mathrm{r}=0,027, \mathrm{p}=0,813)$ ( 1 pav.).

\section{Išvados}

1. Greivso oftalmopatija sergantiems pacientams didžiausią įtaką gyvenimo kokybei turi ir labiausiai vargina akių jautrumas šviesai ir akių niežulys.

2. Greivso oftalmopatija sergantiems pacientams Hertelio egzoftalmetru nustatytas vidutinis dešinès ir kairès akies išverstakumas viršijo normos ribas.

3. Nustatyta statistiškai reikšminga tiesioginè koreliacija tarp išverstakumo dydžio ir akių jautrumo šviesai, niežulio ir skausmo stiprumo.

\section{Literatūra}

1. Sikder S, Gire A, Selter J. The relationship between Graves ophthalmopathy and dry eye syndrome. Clinical Ophthalmology 2014;57.

https://doi.org/10.2147/OPTH.S76583

2. The definition and classification of dry eye disease: report of the definition and classification subcommitee of the international dry eye workshop (2007). The Ocular Surface 2007;5(2):75-92. https://doi.org/10.1016/S1542-0124(12)70081-2

3. Higienos institutas [Internet]. Stat.hi.lt. 2019 [cited 29 May 2019]. Available from: https://stat.hi.lt/default.aspx?report id $=168$ 
4. Bahn R. Graves' ophthalmopathy. New England Journal of Medicine 2010;362(8):726-738.

https://doi.org/10.1056/NEJMra0905750

5. Bartalena L, Tanda M. Graves' ophthalmopathy. New England Journal of Medicine 2009;360(10):994-1001. https://doi.org/10.1056/NEJMcp0806317

6. Jarusaitiene D, Lisicova J, Krucaite A, Jankauskiene J. Exophthalmometry value distribution in healthy Lithuanian children and adolescents. Saudi Journal of Ophthalmology 2016; 30(2):92-97.

https://doi.org/10.1016/j.sjopt.2015.11.005

\section{DRY EYE DISEASE AMONG PATIENTS WITH GRAVES OPTHALMOPATHY}

L.Kapitanovaitė, S.Giedrys, J.Jankauskienè

Keywords: dry eye syndrome, Graves opthalmopathy, dry eye disease, Graves disease, exopthalmetry, ocular surface disease index.

Summary

Dry eye syndrome (DES) in patients with Graves opthalmopathy (GO) is diagnosed in about $65 \%$ - $85 \%$ of all cases. DES is described as a multifactorial ocular surface disease that results in various symptoms of discomfort like aching, burning, blurred vision, etc. In Graves disease DES presents due to increased exopthalmus, retraction of the eyelid and reduced tear production. The aim of this study was to evaluate dry eye syndrome prevalence between patients with Graves opthalmopathy and to evaluate the correlation between the intensity of clinical symptoms and exopthalmus. Methods an original questionnaire was prepared for this study and measurements of eye protrusion were done using Hertel exophthalmometer. The questionnaire included questions about most common symptoms of DES and their impact on patients' daily activities. After evaluating the results conclusions were drawn that sensitivity to light and itchiness of the eye had the biggest impact on patients' life quality. Hertel exopthalmetry showed that exopthalmus of both eyes statistically significantly exceeded the normal range. There was also a statistically significant correlation between exopthalmus and sensitivity to light, itchiness and eye pain.

Correspondence to: kapitanovaite.laura@gmail.com

Gauta 2019-06-25 